\title{
Prevalence and the Level of Knowledge Toward Cigarette Smoking Among Adult Male in Rural Area
}

\author{
Yelvi Levani $^{1 *}$, Annisa Nurida ${ }^{1}$, Sukadiono ${ }^{1}$, Muhammad Thoriq Hakam ${ }^{1}$ \\ ${ }^{1}$ Faculty of Medicine, Universitas Muhammadiyah Surabaya, Surabaya 60113, Indonesia. \\ *Corresponding author. Email: yelvilevani@fk.um-surabaya.ac.id
}

\begin{abstract}
Cigarette smoking is the leading cause of non-communicable diseases such as lung cancer, chronic obstructive pulmonary disease, ischemic heart disease, stroke, and many more. In USA, the prevalence smokers in rural area were higher than in urban or metropolitan area. But there was still no data in Indonesia. The level of knowledge may influence health behaviour, including smoking. This study aimed to know the prevalence of cigarette smokers among adult males in rural areas and to investigate the level of their knowledge about smoking. This study used a cross-sectional design and a consecutive sampling technique. This study used a closed questionnaire to sixty adult males who were attending a meeting in Mojodawu village meeting hall, East Java, Indonesia. Fifty adult males confessed as a smoker (83.3\%) and only ten $(16,7 \%)$ respondents who were not. The level of knowledge among smokers was mostly not good (64\%). Only $46 \%$ of respondents stated that smoking was dangerous to their health, and only $38 \%$ of respondents stated cigarettes harmed people around. This study showed a high prevalence of smokers among adult males in a rural area. Most of the smokers had a lack of knowledge about smoking hazards.
\end{abstract}

Keywords: prevalence, knowledge toward cigarette smoking, male

\section{INTRODUCTION}

Smoking is still one of the biggest public health problems in the world. In 2019, the World Health Organization (WHO) showed that over 1.1 billion people smoked tobacco and $80 \%$ of smokers live in the low-middle country [1]. Smoking kills more than 8 million people each year. Direct tobacco smoking kills more than 7 million people around the world annually, while 1.2 deaths are the result of nonsmokers being exposed to second-hand smoke [1]. Smoking causes more deaths each year than Human Immunodeficiency Virus (HIV), illegal drug use, alcohol use, vehicle motor injuries, and fire-related incidents combined [2].

The prevalence of smoking continues to increase in Indonesia. Data from the Global Adults Tobacco Survey (GATS) survey in 2011 showed that Indonesia had the highest number of active smokers with a male smoker prevalence of $67 \%$ (57.6 million) and a female smoker prevalence of $2.7 \%$ (2.3 million). Indonesia is the thirdlargest cigarette consumer in the world [3]. Based on WHO data in 2015, the prevalence of current tobacco smoking among persons aged 15 years and older was $39.5 \%$, and the majority was male (76.1\%) [4].

By region, the prevalence of cigarette smoking among adults living in rural areas in United States is the highest (28.5\%) [5]. Based on data survey in Indonesia 2011, cigarette smoking is also more prevalent in rural areas (39.1\%) compared to urban areas (33\%) [3]. Daily smoking is higher in rural areas (32.2\%) than in urban areas (26.3\%) [3].
Cigarette smoke contains more than 7,000 chemicals such as formaldehyde, benzene, polonium and many more. It contains hundreds of toxic metals such as chromium, arsenic, lead, and also contains poison gases such as carbon monoxide, hydrogen cyanide, ammonia, butane, and toluene. About 70 chemicals are carcinogenic. There are 25 types of diseases caused by smoking, such as Emphysema, Lung Cancer, Chronic Bronchitis and other Lung Diseases [6]. Smoking affects nearly every organ of the body. Smoking in a pregnant woman can increase preterm delivery, stillbirths, low birth weight, and orofacial cleft in infants. Smoking can reduce man fertility, increase the risk of cataract, diabetes Mellitus type 2, inflammation disease and decreased immune function [7].

Public knowledge of smoking hazards is still low. Although it has been proven about the dangers of smoking, few smokers understand that smoking harms almost every organ of the body and causes many diseases. Most think smoking causes only a few diseases [3]. This study aimed to know the prevalence of cigarette smokers among adult males in rural areas and to investigate the level of their knowledge about smoking hazards.

\section{METHODS}

This study used a cross-sectional design and a consecutive sampling technique. Respondents of this study were male, aged 15 years and older, who were attending a meeting in Mojodawu village meeting hall, East Java, Indonesia. The total respondents of this study were sixty adult males. This study used a closed questionnaire for sixty adult males. Respondents were interviewed for the socio-demographic profile and the level of knowledge using a simple semistructured questionnaire. There were seven true-false statements to assess the respondent's knowledge including 
was only $16.7 \%$. This prevalence is higher compared to data from WHO $2015(76 \%)$ [1] and data from GATS 2015 $(67 \%)$ [9]. The health of people living in rural areas that impacted by smoking is more often because of socioeconomic factors, culture, policies and lack of proper healthcare [10].

Table 3 Prevalence of active smoker

\begin{tabular}{|lr|}
\hline Smoking status & Percentage \\
\hline Active Smoker & $83.3 \%$ \\
Non-Smoker & $16.7 \%$ \\
\hline
\end{tabular}

The level of knowledge has been assessed by using a simple semi-structured questionnaire. The level of knowledge was classified into two classes; high and low. The level of knowledge was low if the score below average. The level of knowledge was high if the score above average. The number of respondents who had a high level of knowledge was $21(35 \%)$, and the number of respondents who had a low level of knowledge was $39(65 \%)$. There is strong correlation between smoking and the level of knowledge $(\mathrm{p}=0.000)$.

Table 4 The level of the respondent's knowledge

\begin{tabular}{|lc|}
\hline Level of knowledge & Percentage \\
\hline Good knowledge & $36.0 \%$ \\
Bad knowledge & $64.0 \%$ \\
\hline
\end{tabular}

Overall the respondent's level of knowledge was not good. Half of the respondents (46\%) answered the smoking was not dangerous to themselves, and most of the respondents $(62 \%)$ answered smoking was not harmful to others. Knowledge can influence health behaviour including not smoking [11]. The level of knowledge is also related to the level of education. This study showed that most of the respondents had a low level of knowledge about smoking hazards.

Table 5 Smoking hazards

\begin{tabular}{|lc|}
\hline Is smoking dangerous? & Percentage \\
\hline Dangerous & $46.0 \%$ \\
Not Dangerous & $54.0 \%$ \\
\hline
\end{tabular}

Table 6 Smoking hazards to people surrounding

Table 2 Level of Respondent's Income

\begin{tabular}{|cc|}
\hline Income & Percentage \\
\hline > IDR 500.000 & $33.3 \%$ \\
IDR 500.000-1.000.000 & $50.0 \%$ \\
IDR 1.000.000-2.000.000 & $11.7 \%$ \\
IDR 2.000.000-3.000.000 & $1.7 \%$ \\
> IDR 3.000.000 & $3.3 \%$ \\
\hline
\end{tabular}

\subsection{Prevalence of Smoking and The Level of Knowledge About Smoking Hazards}

Current active smokers were defined as persons who smoke daily basis or occasionally. The prevalence of smoking in respondents was $83.3 \%$, and the prevalence of non-smoker

\begin{tabular}{|lc|}
\hline Is smoking harmful to others? & Percentage \\
\hline Harmful others & $38.0 \%$ \\
Not harmful & $62.0 \%$ \\
\hline
\end{tabular}

More than half of the respondents did not know if smoking was dangerous to their health and harmful to people's surroundings. A low level of knowledge about smoking hazards leads to smoking behaviour. The smokers usually smoked in random places including at home and public places. This habit is dangerous, because people surround them, including children and pregnant woman can be affected by second-hand smoke.

Socioeconomic is also influence smoking behaviour. This study showed that most of the respondents had a low level of economic. Most of them were a farmer with income less 
[5] CDC. Tobacco use by geographic region. Tobaccorelated disparities. 2019. Available from:

https://www.cdc.gov/tobacco/disparities/geographic/ind ex.htm

[6] U.S. Department of Health and Human Services. How Tobacco Smoke Causes Disease: What It Means to You. Atlanta: U.S. Department of Health and Human Services, Centers for Disease Control and Prevention, National Center for Chronic Disease Prevention and Health Promotion, Office on Smoking and Health, 2010.

[7] U.S. Department of Health and Human Services. The Health Consequences of Smoking - 50 Years of Progress: A Report of the Surgeon General. Atlanta: U.S. Department of Health and Human Services, Centers for Disease Control and Prevention, National Center for Chronic Disease Prevention and Health Promotion, Office on Smoking and Health, 2014

We want to thank the Faculty of Medicine Muhammadiyah University of Surabaya, Ikatan Mahasiswa Muhammadiyah, and head of Mojodawu Village, Mojokerto, East Java, Indonesia.

\section{REFERENCES}

[1] WHO. Tobacco. Key facts: Tobacco. 2019. Available from: https://www.who.int/news-room/factsheets/detail/tobacco

[2] Mokdad AH, Marks JS, Stroup DF, Gerberding JL. Actual Causes of Death in the United States. JAMA: Journal of the American Medical Association 2004;291(10):1238-45

[3] SEARO-WHO. Global Adult Tobacco Survey: Indonesia Report 2011. WHO library cataloguing-inpublication data. 2012. Available from:

http://www.searo.who.int/tobacco/data/gats_indonesia 2011.pdf

[4] WHO. Prevalence of Tobacco Smoking. Global Health Observatory (GHO) Data. 2016. Available from: https://www.who.int/gho/tobacco/use/en/
[8] Park SE, Lee K, Yun SN, Cui W. Structural model of factors influencing smoking behavior among Korean-Chinese adolescent boys. Applied Nursing Research. 2014. 27(3),192-197.

[9] Asma S, Mackay J, Song SY, Zhao L, Morton J, Palipudi KM, et al. The GATS atlas. 2015. CDC Foundation, Atlanta, GA.

[10] American Lung Association. Cutting Tobacco's Rural Roots: Tobacco Use in Rural Communitiesexternal icon. Chicago: American Lung Association, 2015

[11] Islam, S. M. S., \& Johnson, A. Influence of known psychosocial smoking risk factors on Egyptian adolescents' cigarette smoking behavior. Health Promotion International. 2005, 20(2), 135-145

[12] WHO. WHO Global report on mortality attributable to tobacco. WHO library cataloguing-inpublication data. 2012. Available from: https://apps.who.int/iris/bitstream/handle/10665/44815/ 9789241564434 eng.pdf;jsessionid=1A2CC4C8BEC9 $\underline{\mathrm{A} 81 \mathrm{~F} 53127 \mathrm{FA} 81 \mathrm{~B} 0 \mathrm{BAEC} 2 \text { ? }}$ sequence $=1$ 